\title{
Supplementation with Urea and Molasses and Body Weight, Milk Yield and Onset of Ovarian Cyclicity in Cows
}

\author{
M. Golam Shahi ALAM ${ }^{1)}$, Md. Shakif UL-AZAM ${ }^{2)}$ and Md. Jasimuddin KHAN²) \\ ${ }^{1)}$ Department of Surgery and Obstetrics, Faculty of Veterinary Science, Bangladesh \\ Agricultural University, Mymensingh, ${ }^{2)}$ Veterinary Surgeon, Dhaka Zoological Garden, \\ Department of Livestock Services, Mirpur and ${ }^{3)}$ Department of Animal Nutrition, Faculty of \\ Animal Husbandry, Bangladesh Agricultural University, Mymensingh, Bangladesh
}

\begin{abstract}
Ten multiparous crossbred local Zebu cows were randomly divided into two nutritional groups (A and B) to determine the effect of urea-molasses-mineral block supplementation on body weight gain, milk production, and onset of ovarian cyclicity after calving. Both groups had farm rations daily, but the supplemented group (B) was provided with an additional diet daily of $250 \mathrm{~g}$ urea-molasses-mineral block. The cows in group A required 80-120 days (98.0 \pm 6.7 days) until peak milk progesterone concentrations and 60-80 days (72.0 \pm 3.8 days) were required for group $B(p<0.05)$. Group B needed a shorter period for expression of standing estrus (91-101 days; mean $96.2 \pm 2.3$ days) than group A [130-153 (141.6 \pm 4.6$)$ days; $\mathrm{p}<0.01]$. For groups A and B, body weight gain was $8.4 \pm 3.4$ $\mathrm{kg}$ and $18.4 \pm 3.2 \mathrm{~kg}$, respectively $(\mathrm{p}<0.01)$. The average milk production of groups $\mathrm{A}$ and $\mathrm{B}$ were $3.3 \pm$ 1.0 and $4.8 \pm 1.6 \mathrm{~L} /$ day, respectively $(\mathrm{p}>0.05)$. There was linear improvement in milk yield from Day 60 postpartum up to Day 90 of lactation in group B (supplemented). However, in group A, milk production decreased starting on Day 40 after parturition.

Key words: Zebu cows, Urea-molasses-mineral-block, Supplementation, Milk yield, Ovarian rebound, Postpartum
\end{abstract}

(J. Reprod. Dev. 52: 529-535, 2006)

$\mathbf{T}$ he relationships between food intake during lactation and onset of first estrus after parturition are of considerable practical importance in dairy farming [1]. Body hemostasis in early lactation is altered through mobilization of depot fat and skeleton muscle breakdown, which favour discrimination of absorbed nutrients to the mammary glands to provide sufficient substrate for milk synthesis [2]. The reproductive performance of the postpartum cow is related to the body condition of the cow concerned [3]. Cows fed a high-energy rich diet after calving conceives sooner

Accepted for publication: April 12, 2006

Published online: May 23, 2006

Correspondence: Dr. M.G.S. Alam

(e-mail: mizanlr@royalten.net.bd) than cows with lower energy intake [4]. It has been reported that glucose and cholesterol might influence the interval from calving to conception in high yielding dairy cows [5].

Rice straw is the staple food for dairy cattle in Bangladesh, and it is the main source of energy for cattle [6]. It contains very little energy and protein, and this is responsible for low milk production and poor fertility in cows in Bangladesh. Ureamolasses-multinutrient-block (UMMB) is used to supplement straw-based diets in dairy cattle production [7]. The urea in UMMB furnishes readily available nitrogen to the rumen microbes, which they use to produce protein for growth. Molasses provides energy and sulphur to the rumen microbes. The supply of nitrogen, energy, 
Table 1. Cows supplied with normal and UMMB-supplemented rations

\begin{tabular}{|c|c|c|c|}
\hline Breeds & No. of lactations & Initial body weigh $(\mathrm{kg} ;$ mean $\pm \mathrm{SE})$ & Rations (kg/cow/day) \\
\hline $\begin{array}{l}\text { Non-supplemented group A } \\
\text { (Sahiwal × Sindhi cross; } \\
\text { Jersey cross; Sahiwal cross; } \\
\text { Red-Chittagong) }\end{array}$ & $3-8$ & $240.0 \pm 30.6(214-226)$ & 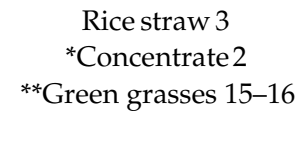 \\
\hline $\begin{array}{l}\text { UMMB supplemented group B } \\
\text { (Red-Chittagong; Jersey cross; } \\
\text { Holstein cross) }\end{array}$ & $1-5$ & $263.0 \pm 57.4(185-345)$ & $\begin{array}{c}\text { Rice straw } 3 \\
\text { *Concentrate } 2 \\
* * \text { Green grasses 15-16 } \\
\text { UMMB } 0.25\end{array}$ \\
\hline
\end{tabular}

${ }^{*}$ Concentrate mixture contained 4 parts wheat bran, 2 parts rice polish and oil cake, and one part common salt. ${ }^{* *}$ Green grasses contained mainly Para, Napier, and roadside grasses.

Table 2. Components used for preparation of $U M M B$

\begin{tabular}{lc}
\hline Components & Weight/volume (\%) \\
\hline Molasses & 55.0 \\
Wheat bran & 25.0 \\
Urea & 2.0 \\
Fish-meal & 5.0 \\
Calcium oxide & 5.0 \\
Mstard oil cake & 5.0 \\
Common salt & 1.0 \\
Biomix-DB $^{1}$ & 2.0 \\
\hline
\end{tabular}

${ }^{1}$ Mineral mixture (Techno Drugs, Segunbagicha, Dhaka, Bangladesh).

and sulphur from UMMB increases the rate of degradation of fibrous substance like rice straw, and supplementation of a straw-based diet with a UMMB diet increases milk production with a concomitant improvement of reproduction in cattle [8].

This study was undertaken under the farming condition in Bangladesh to evaluate the effects of supplementation with UMMB on resumption of ovarian cyclicity, milk production, and live weight gain in postpartum cows.

\section{Materials and Methods}

\section{Experimental animals and their management}

Ten multiparous lactating crossbred local Zebu cows weighing between $214.0-345.0 \mathrm{~kg}$ were selected immediately after calving. The cows were randomly divided into two groups (A and B). All cows were mainly stall-fed and were sometimes tethered during the experimental period. From the day of calving, the cows of both groups (A and B) were supplied the normal rations of the farm. In addition, each cow in group B was supplemented with $250.0 \mathrm{~g}$ of UMMB per day. After morning milking, from $0800 \mathrm{~h}$ to $1600 \mathrm{~h}$, all cows were allowed to graze in a confined area of the adjacent dairy farm. All animals had free access to drinking water ad libitum. The experimental cows were kept under the same management conditions. Details of the feed rations including supplementation are given in Table 1. The cows were checked for estrus twice daily by careful visual observation [9]. Animals with signs of "slimming" or "bulling string" and/or that stood to be mounted by a herd mate were confirmed to be cows in estrus.

\section{Preparation of UMMB block}

The supplemented feed components used in this experiment are given in Table 2. Briefly, mustard oil cake and urea were mixed separately in an aluminium can with a little water the day before preparation of the UMMB block. Wheat bran and molasses were mixed together and were then mixed with urea, mustard oil cake, fish-meal, common salt, and Biomix-DB (Techno Drugs, Dhaka, Bangladesh), a mineral mixture $(10,000,000$ IU vitamin A, 1,000,000 IU vitamin D, $10.0 \mathrm{~g}$ vitamin E, $0.80 \mathrm{~g}$ cobalt, $6.0 \mathrm{~g}$ copper, $80.0 \mathrm{~g}$ iron, 2.5 $\mathrm{g}$ iodine, $50.0 \mathrm{~g}$ manganese, $100.0 \mathrm{~g}$ magnesium, 0.1 $\mathrm{g}$ selenium, $45.0 \mathrm{~g}$ zinc per $1000.0 \mathrm{~g}$ ). Then, the binding agents, calcium oxide, and other feed ingredients were well mixed together by hand on a concrete floor. After thorough mixing, the mixture was placed into a rectangular brick-shaped wooden frame to produce a block and was then covered with a polythene sheet. After solidification, the UMMB blocks were cut into 250.0 g portions and stored at room temperature until use. 
Table 3. Proximate analyses of the feed components used in formulation of the experimental ration on a dry matter (DM) basis

\begin{tabular}{lcccc}
\hline Feed components & DM\% & CP\% & EE\% & Ash\% \\
\hline Napier grass & 26.8 & 9.2 & 2.3 & 16.0 \\
Para grass & 27.8 & 10.0 & 2.9 & 11.2 \\
Rice straw & 89.0 & 3.0 & 1.9 & 12.0 \\
Biomix-DB & 93.8 & 0.8 & 4.0 & 11.1 \\
Wheat bran & 85.6 & 13.6 & 2.7 & 6.5 \\
Urea & 91.7 & 287.5 & - & - \\
Calcium oxide & 95.9 & - & - & 87.0 \\
Common salt & 95.6 & - & - & 91.2 \\
Molasses & 75.6 & 5.9 & 3.8 & 12.0 \\
UMMB & 76.6 & 16.3 & 1.5 & 14.5 \\
Fish meal & 89.9 & 48.6 & 10.4 & 10.3 \\
Mustard oil cake & 90.0 & 36.8 & 11.6 & 10.3
\end{tabular}

\section{Proximate analyses of the feed}

All feed components were analysed for the diets [10], and the total percentages of dry matter $(\mathrm{DM} \%)$, crude protein $(\mathrm{CP} \%)$, ether extracts $(\mathrm{EE} \%)$, and ash were estimated and recorded for the individual feed components. The results of the proximate analyses are presented in Table 3.

\section{Productive information}

At the beginning of the experiment, the initial body weights of the individual postpartum cows were recorded using a Rando tape (HauptnerInstrumente $\mathrm{GmbH}, \mathrm{CH} 8304$ Wallisellen, Switzerland) by measuring the chest circumference of the cow behind the elbows. From the circumference in centimetres, the live weights in kilograms were estimated on the reverse side of the tape. The body weights of all experimental cows were measured immediately after parturition and every 10 days beginning on the day of calving until the onset of clinical signs of postpartum estrus.

The cows were hand-milked twice daily, and the quantities of morning and evening milk yields were recorded to obtain the actual quantity of milk produced by each cow per day. Before milking, calves were allowed to briefly suckle to stimulate the teats of the cows. Calves were kept on their feet during the milking period.

\section{Progesterone radioimmunoassay (RIA)}

Skim milk was used for analysis of progesterone concentrations. Milk samples $(10 \mathrm{ml})$ were collected from individual cows into tubes containing an $8 \mathrm{mg}$ sodium azide tablet (MERCK,
Germany) at 10 day intervals starting at parturition until the animals showed signs of standing estrus. The milk samples were centrifuged at room temperature for $15 \mathrm{~min}$ at $1000 \mathrm{~g}$ to remove fat particles before the skimmed milk was assayed for progesterone. The solid-phase radioimmunoassay technique was used as described by the Joint FAO/ IAEA Division, Vienna, Austria, using ${ }^{125}$ I-labelled progesterone as the tracer. Progesterone profiles of $>3.0 \mathrm{nmol} / \mathrm{L}$ were considered to be of luteal origin. The intra and inter assay coefficient of variations were $6.3 \%(n=13)$ and $9.0 \%(n=3)$, respectively. The percentage binding at zero level was $31.0 \pm 2.3$, and the assay sensitivity was $0.6 \mathrm{nmol} / \mathrm{L}$.

\section{Statistical analysis}

All the recorded and calculated data were analysed using the SPSS statistical computer package for the analysis of variance. Results are given as means \pm standard error of the mean. The data were analysed using the Student's $t$-test. ANOVA was performed to compare data among selective treatments.

\section{Results}

At 10 days after calving, body weight loss had occurred in both groups of cows; however, the body weights had started to increase by 20 days after calving (Fig. 1). Starting on Day 20 after calving, there was a linear increase in body weight gain throughout the rest of the experimental period. There was a significant $(p<0.01)$ difference 


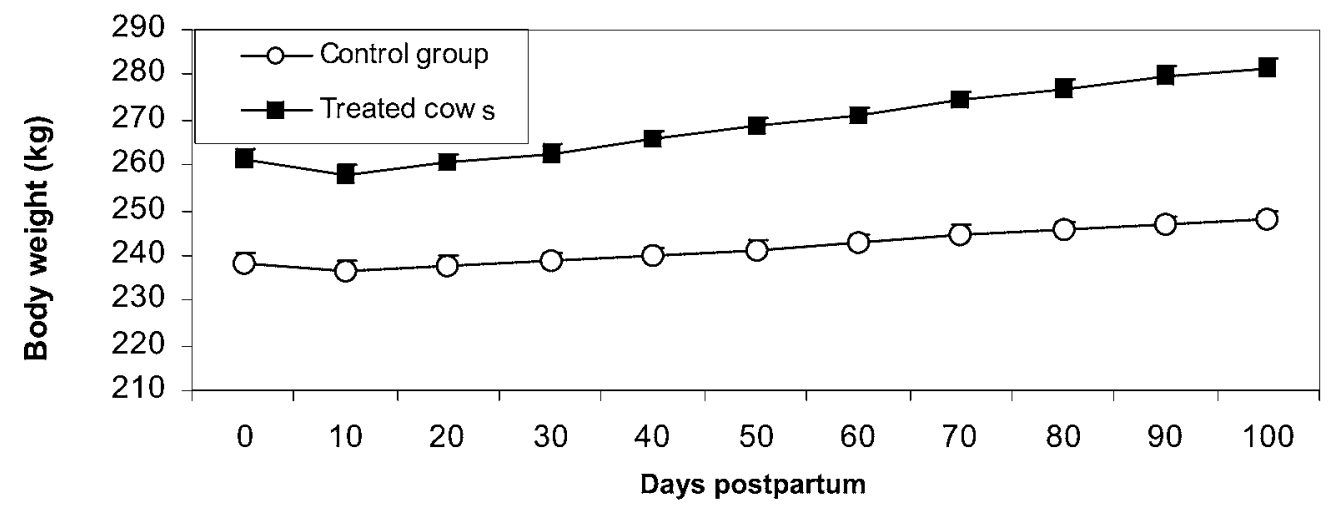

Fig. 1. Body weight changes of the control and UMMB-supplemented groups of cows

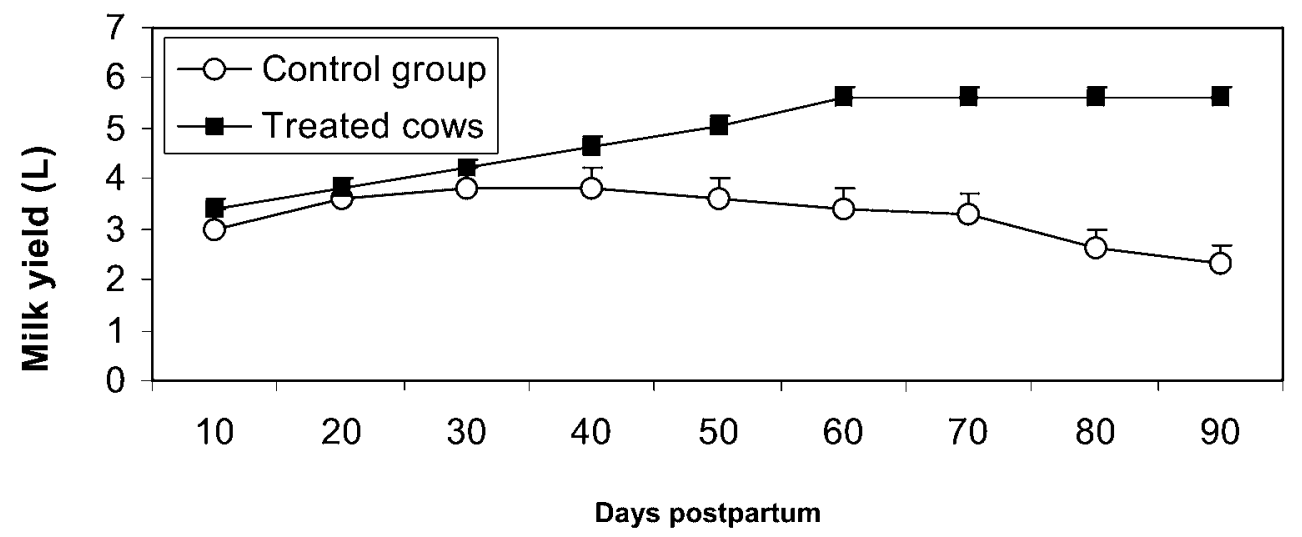

Fig. 2. Changes in milk yield of the control and UMMB-supplemented groups of cows

in net body weight gain between the control nonsupplemented (group A) and UMMBsupplemented (group B) cows $(8.4 \pm 3.4 \mathrm{~kg}$ and 18.4 $\pm 3.2 \mathrm{~kg}$, respectively).

There was linear improvement in milk yield until Day 60 of calving in the supplemented group of cows (group B) that remained at a plateau up to Day 90 postpartum. In the non-supplemented control group of cows (group A), milk production decreased starting on Day 40 of lactation (Fig. 2). The average milk productions of the groups ( $\mathrm{A}$ and B) were $3.3 \pm 1.0 \mathrm{~L}$ and $4.8 \pm 1.6 \mathrm{~L}$ per day, respectively. Total milk production for groups $\mathrm{A}$ and $\mathrm{B}$ were $297.0 \pm 3.1 \mathrm{~L}$ and $432.0 \pm 4.1 \mathrm{~L}$, respectively. The milk yield was higher for the UMMB-supplemented group of cows; however, the difference was not statistically significant ( $\mathrm{p}>0.05$ ).

After supplementation of UMMB, ovarian activity, as monitored by measurement of milk progesterone concentrations, showed a shorter interval between calving and peak milk progesterone concentrations that ranged from 6080 days postpartum $(72.0 \pm 3.8$ days, $n=5)$. For the non-supplemented control group of cows (group A), the interval for detecting peak milk progesterone concentrations after calving ranged from 80-120 days (98.0 \pm 6.7 days, $n=5$; Table 4). The ovarian responses, as measured by progesterone concentration of both groups are shown in Fig. 3.

The interval between calving and onset of standing estrus was 130-153 (141.6 \pm 4.6$)$ days in group A (non-supplemented control) and 91-101 $(96.2 \pm 2.3)$ days in group B (UMMB-supplemented; Table 4). The UMMB-supplemented group of postpartum cows expressed estrus signs earlier than the non-supplemented controls $(\mathrm{p}<0.01)$. 
Table 4. Calving to peak milk progesterone concentration and estrus in the cows of group A (non-supplemented control) and group B (UMMB-supplemented)

\begin{tabular}{ccc}
\hline Groups & $\begin{array}{c}\text { Calving to highest progesterone } \\
\text { (mean } \pm \text { SE; days) }\end{array}$ & $\begin{array}{c}\text { Calving to standing estrus } \\
\text { (mean } \pm \text { SE; days) }\end{array}$ \\
\hline $\begin{array}{c}\text { A } \\
\text { (Non-supplemented; } \mathrm{n}=5)\end{array}$ & $98.0 \pm 6.7(80-100)$ & $141.6 \pm 4.6(130-153)$ \\
\hline $\begin{array}{c}\text { B } \\
\text { (UMMB-supplemented; } \mathrm{n}=5)\end{array}$ & $* 72.0 \pm 3.8(60-80)$ & $* * 96.2 \pm 2.3(91-101)$ \\
\hline
\end{tabular}

${ }^{*}=$ Significant at the $5 \%$ level. ${ }^{* *}=$ Significant at the $1 \%$ level.

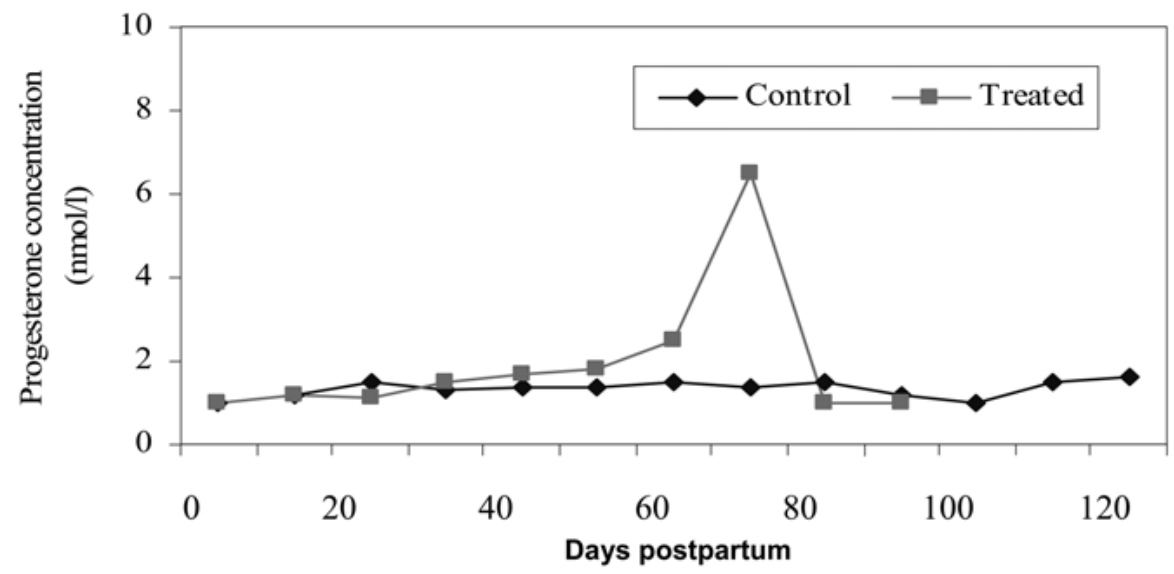

Fig. 3. Milk progesterone concentrations of lactating cows

\section{Discussion}

The body weight of the UMMB supplemented cows increased by $18.4 \pm 3.2 \mathrm{~kg}$ after supplementation, whereas the body weight of the controls increased $8.4 \pm 3.4 \mathrm{~kg}$ in the same period. Similar body weight gains of $4.8 \%$ during the $3-$ month period after calving have been reported previously in supplemented cows [7]. From Day 20 after calving, a linear improvement in body weight occurred throughout the rest of the experimental period. The degree of energy deficit in the first 20 days postpartum may have a significant effect on the time of first ovulation in dairy cows [11]. Nutritional supplementation is one of the most important determinants of body weight, especially in postpartum cows $[12,13]$. Significantly $(p<0.01)$ greater live weight gain was observed in the UMMB-supplemented group than in the control non-supplemented cows (Fig. 1). It has been reported that body weight loss is greatest during the second week of lactation and that cows start to gain body weight by the fifth week of lactation [14]. In this study, early weight loss was evident at Day 10 after calving, and this was similar to a previous study [14]. However, body weight started to increase on Day 20 post-calving after supplementation with UMMB.

The results of this work revealed that UMMB has a positive effect on milk yield in cows, and this may be due to supply of nitrogen resulting in more intake and utilization of straw. Cows use fibre as an energy source via fermentation by the rumen microbes for the maintenance of their ecosystem, particularly to allow symbioses between protozoa and bacteria. Rumen bugs also need energy to survive and produce microbial protein. It has been suggested that the negative energy balance during late pregnancy and early lactation interrupts ovarian function by suppressing gonadotropin synthesis and release [15]. Changes in body weight and linear improvement of milk yield with an earlier onset of postpartum behavioural estrus indicate that the supplemented cows maintained 
their production requirements better than the control cows. Thus, the energy balance in early lactation is important in determining earlier ovarian rebound [13]. The reproductive efficiency of cows after calving is largely dependent on energy balance $[16,17]$. It is important to maximize intake of high-energy feed early in lactation to attain best reproductive performance and milk yield. It is generally indicated that adequate energy intake is more critical than protein intake for maintaining reproductive function [18, 19]. Dairy cows should not be fed more than $16 \%$ crude protein in the total diet reduces pregnancy rate. Under practical conditions, energy status, particularly at the time of parturition, is most likely to be the major limiting factor affecting the onset of ovarian cyclicity in postpartum cows [20]. It has also been suggested that various hormones and metabolites play important roles in energy homeostasis in lactating dairy cows [21].

It has been observed that energy availability is very important in regulating gonadal function through the release of GnRH/LH at various reproductive phases in ruminants [22]. It has also been demonstrated that fasting or glucose deprivation suppresses pulsatile release of $\mathrm{LH}$ in ruminants. Energy deficiency is detected by specific central sensors and is conveyed to the hypothalamus to regulate LH release and food intake [23]. It is evident that metabolic hormones, particularly insulin and IGFs, interact with gonadotropins at the level of the gonads to stimulate cell proliferation and hormone production [24]. This clearly indicates that nutrition can influence a whole range of reproductive parameters, however; the pathways through which nutrition acts in dairy cows have not yet been elucidated. We suggest that the energy and protein requirements have important interactions and that there is no benefit formulating energy or protein standards in isolation.

The interval from calving to peak progesterone concentration in the control group was longer than that of the supplemented group. Expression of behavioural estrus after the postpartum period in the supplemented group was also earlier than in the control group. This result supports previous reports $[7,25]$. It has been reported that elevation of progesterone concentrations in body fluid occurs in up to $50 \%$ of cows before first expression of signs of estrus $[26,27]$. This could be due to incomplete maturation of follicles, which leads to a reduction in luteal steroidogenesis. It has been suggested that cows cycling regularly $>90$ days postpartum are more responsive to exogenous $\mathrm{GnRH}$, possibly due to further maturation of the hypothalamuspituitary axis after cyclical exposure to alternating plasma progesterone and estradiol concentrations [28].

We conclude that the UMMB may have a positive effect on the productive and reproductive performances of cows maintained on straw-based diets. However, care should be taken with regard to circulating urea from feeding of UMMB as it may adversely affect early embryonic development [29].

Further work on the use of UMMB at the smallholder level in rural areas of Bangladesh is needed before any recommendations can be given, but we believe that their potential importance is obvious.

\section{Acknowledgements}

We are grateful to Dr. W. R. Ward (University of Liverpool, England) for reviewing the manuscript. Thanks are also extended to Professor Kei-ichiro Maeda (Nagoya University, Japan) for his encouragement and support.

\section{References}

1. Khan AA, Islam MN, Khan MAS, Akbar MA. Effect of restricted and ad libitum feeding during late pregnancy on the performance of crossbred cows and their calves. Asian-Austra J Anim Sci 2002; 15: 1267-1270.

2. Bauman DE, Peel CJ, Steinhour WD, Reynolds PJ, Tyrrell HF, Brown ACG. Effects of bovine somatotropin on metabolism of lactating dairy cows: influence on rates of irreversible loss and oxidation of glucose and nonesterified fatty acids. $J$ Nutr 1988; 118: 1031-1040.

3. Van Nieker A. The effect of body condition as influenced by winter nutrition on the reproductive performance of the beef cow. S Afric J Anim Sci 1982; 
12: $383-387$.

4. Hill JRDR, Lamord DM, Henricks JF, Dickey GD, Nirwender NW. The Effects of under nutrition on ovarian function and fertility in beef heifer. Biol Reprod 1970; 2: 78-84.

5. Reist M, Erdin DK, Euw DV, Tschumperlin KM, Leuenberger $\mathrm{H}$, Hammon $\mathrm{HM}$, Morel C, Philipona C, Zbinden Y, Kunzi N, Blum JW. Postpartum reproductive function: association with energy, metabolic and endocrine status in high yielding dairy cows. Theriogenology 2003; 59: 1707-1723.

6. Reza A. The energy role of cattle in the Bangladesh agro-ecosystem. Ecol Engg 1998; 10: 221-226.

7. Ghosh A, Alam, MGS, Akbar MA. Effect of urea molasses mineral block supplementation on postpartum ovarian activity in Zebu cows. Anim Reprod Sci 1993; 31:61-67.

8. Fitzpatrick LA, Fordyce G, McSseeney CS, Schilink AC, Jolly PD, Entwistle KM. Nutritional and managemental techniques for controlling postpartum anoestrus in tropical beef cattle. First Research Coordination Meeting and Training Workshop, Animal Production and Health Section, FAO/IAEA; 1989; Kuala Lumpur, Malaysia.

9. Ball P. Fertility problems in dairy herds. In Practice, November 1983; 189-194.

10. AOAC. Official Methods of Analysis. Association of Official Analytical Chemists (15 th ed), 1990; Washington, DC.

11. Kelly J. Nutrition of the dairy cow. In: Anthony HA (ed.), The Health of Dairy Cattle. Oxford: Blackwell Science 2002; 49-107.

12. Sasser RG, Williams RT, Bull RC, Ruder CA, Falk DG. Postpartum reproductive performance of crude protein restricted beef cows: return to estrus and conception. J Anim Sci 1988; 65: 31-42.

13. Butler WR, Smith RD. Inter-relationship between energy balance and postpartum reproductive function in dairy cattle. J Dairy Sci 1989; 72: 767-783.

14. Guthrie DL, West JW. Nutrition and reproduction interactions in dairy cattle. The University of Georgia College of Agricultural and Environmental Sciences USA 1994; (Bulletin iiii).

15. Dobson H, Alam MGS. Preliminary investigations into the endocrine systems of subfertile cattle: location of common lesion (rate-limiting step). J Endocr 1987; 113: 167-171.

16. Britt JH. Relationships between post-partum nutrition, weight loss and fertility. Cattle Practice 1995; 3: 79-83.

17. Ferguson JD. Diet, production and reproduction in dairy cows: In: North American Nutrition Conferences III Animal Feed Science and Technology 1996; 59: 173-184.
18. Oxreinder SL, Wagner WC. Effect of lactation and energy intake on postpartum ovarian activity in the cow. J Anim Sci 1988; 33: 1127-1131.

19. Jonsson NN, McGowan MR, WcGuigan K, Davison TM, Hussain AM, Kafi M. Matschoss A. Relationship among calving season, heat load, energy balance and postpartum ovulation of dairy cows in a subtropical environment. Anim Repod Sci 1997; 47: 315-326.

20. Nolan CJ, Bull RC, Sasser RG, Rudder CA, Parilasigui PM, Reeves JJ. Postpartum reproduction in protein restricted beef cows: Effect on the hypothalamo-Pituitary-ovarian axis. J Anim Sci 1988; 66: 3208-3212.

21. Lucy MC, Beck J, Staples CR, Head HH, del la Sota RL, Thatcher WW. Follicular dynamics, plasma metabolites, hormones and insulin-like growth factor I (IGF-I) in lactating cows with positive or negative energy balance during the preovulatory period. Reprod Nutr Dev 1992; 32: 331-341.

22. Ohkura S, Tanaka T, Nagatani S, Bucholtz DC, Tsukamura H, Maeda KI, Foster DL. Central, but not peripheral, glucose-sensing mechanisms mediate glucoprivic suppression of pulsatile luteinizing hormone secretion in the sheep. Endocrinology 2000; 141: 4472-4475.

23. Maeda KI, Kinoshita M, Moriyama R, Tsukamura H. A rat model for the energetic regulation of gonadotropin secretion: role of glucose-sensing mechanism in the brain. Domes Anim Endocr 2003; 25: 109-120.

24. Webb R, Gosden RG, Telfer EE, Moor RM. Factors affecting folliculogenesis in ruminants. Anim Sci 1999; 68: 257-284.

25. Patil JS, Despande BR. Study on the body weight changes antepartum, parturition and postpartum periods in Gir cows with special reference to exhibition of postpartum oestrus. Ind Vet J 1981; 58: 376-379.

26. Webb R, Lamming GE, Haynes NB, Foxcroft GR. Plasma progesterone and gonadotrophin concentrations and ovarian activity in post partum dairy cows. J Reprod Fert 1980; 59: 133-143.

27. Alam MGS, Ghosh A. Plasma and milk progesterone concentrations and early pregnancy in Zebu cows. Asian-Austra J Anim Sci 1994; 7: 13-36.

28. Alam MGS, Dobson H. Pituitary responses to a challenge test of GnRH and oestradiol benzoate in postpartum and regularly cyclic dairy cows. Anim Reprod Sci 1987; 14: 1-9.

29. Butler WR. Review: Effect of protein nutrition on ovarian and uterine physiology in dairy cattle, J Dairy Sci 1998; 81: 2533-2539. 